\title{
THE SUBTLE SHIFT FROM MINERAL TRIOXIDE AGGREGATE TO BIODENTINE- A REPORT
}

\author{
Dr. Abarajithan. M, Dr. Sathana. V, Dr. Anitha. M
}

Mohan's Micro-Dentistry, Virudhunagar, Tamilnadu, India

\section{To access $\&$ cite this article}

\section{Website: jidam.idamadras.com}

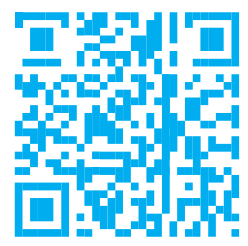

DOI:10.37841/jidam_2020_V7_I3_08

\section{ABSTRACT}

Bio-active materials have been a game changer in restorative dentistry and endodontics over the last few years, but there still exists a lot of confusion and doubts for a general practitioner on the basic differences between MTA(Mineral trioxide aggregate) and BIODENTINE, how to choose one among them. This short compilation will give a quick idea for a clinician about the major difference between both in a nutshell.

KEY WORDS: MTA, Biodentine, Bioceramics

\section{Address for Correspondence:}

Dr. Abarajithan. M, MDS.,

Clinical Head,

Mohan's Micro Dentistry,Virudhunagar,

Tamilnadu, India

Email id: abarajithanmohan@gmail.com

Received : :04.09.2020

Accepted : : 12.09.2020

Published : 27.09.2020 


\section{INTRODUCTION:}

Over the last two decades, the field of endodontics in dentistry is flourishing high. The increased awareness of patients to preserve and restore their natural teeth to function, is one of the main reasons for it. This has ultimately led to new horizons in material sciences too.

The introduction of bioceramics in endodontics is a boom. The cases which were once considered as impossible to treat were all treated with this magnificent material. The remarkable biocompatible material called MTA(Mineral trioxide aggregate) is a breakthrough. It almost replaced the calcium hydroxide-based cements. MTA was found in 1993 by Dr. Mahmoud Torabinejad et $\mathrm{al}^{1}$ at the Loma Linda University, California, US. The applications of this material were in both surgical and non-surgical procedures including indirect pulp capping, perforation repair, root canal filling, apexification and root end filling ${ }^{2}$. Despite the high efficacy of this wonder cement, there were also some crucial properties reported by the clinicians mainly difficult handling, discoloration of tooth structure and increased setting time ${ }^{3}$.

To overcome this, another bioactive material called Biodentine was launched in 2010 by Septodont which is considered the second breakthrough in bioactive materials in endodontics. Biodentine was formulated using the MTA based technology, and hence there is improved properties. It is also claimed as "the dentin substitute" by the manufacturers. This cement has a lesser setting time and more improved handling properties. The compressive, flexural and push out bond strengths are all greater in biodentine when compared to $\mathrm{MTA}^{4}$. This tabular column below is a short compilation which comparatively analyses MTA and biodentine in a clinician point of $\mathrm{view}^{5,6,7,8}$.

\begin{tabular}{|c|c|c|c|}
\hline PROPERTIES & BIO DENTIN & MTA & \\
\hline Form & $\begin{array}{l}\text { Capsule (Single use and } \\
\text { needs an amalgamator) }\end{array}$ & Powde & liquid \\
\hline $\begin{array}{l}\text { Composition (Same main } \\
\text { core material which includes } \\
\text { tricalcium silicate, dicalcium } \\
\text { silicate) plus }\end{array}$ & $\begin{array}{l}\text { Zirconium oxide } \\
\text { Iron oxide }\end{array}$ & $\begin{array}{l}\text { Tetrac } \\
\text { Bismu } \\
\text { Silicor } \\
\text { Alumi }\end{array}$ & $\begin{array}{l}\text { m aluminoferrite } \\
\text { ide } \\
\text { le } \\
\text { oxide }\end{array}$ \\
\hline Setting reaction & $\begin{array}{l}\text { Sets by hydration but it } \\
\text { contains calcium chloride } \\
\text { which acts an accelerator }\end{array}$ & Sets by & ration \\
\hline Setting time & $\begin{array}{l}\text { Initial setting time: } 6 \mathrm{~min} \\
\text { Final setting time: } 10 \mathrm{~min}\end{array}$ & $\begin{array}{l}\text { Initial } \\
\text { Final s }\end{array}$ & $\begin{array}{l}\text { g time: } 70 \mathrm{~min} \\
\text { g time: } 175 \mathrm{~min}\end{array}$ \\
\hline Compressive strength & $\begin{array}{l}\text { First hour: } 100 \mathrm{Mpa} \\
24 \text { hours: } 200 \mathrm{Mpa} \\
1 \text { month: } 300 \mathrm{Mpa}\end{array}$ & $\begin{array}{l}24 \text { hou } \\
21 \text { day }\end{array}$ & $\begin{array}{l}0 \mathrm{Mpa} \\
\mathrm{Mpa}\end{array}$ \\
\hline Porosity & $\begin{array}{l}\text { Due to decreased water } \\
\text { content in the mixing stage, } \\
\text { it exhibits lower porosity. }\end{array}$ & $\begin{array}{l}\text { Due } t \\
\text { mixing }\end{array}$ & $\begin{array}{l}\text { reased water content in the } \\
\text { e, porosity occurs. }\end{array}$ \\
\hline
\end{tabular}


Abarajithan et al : The Subtle Shift from MTA to Biodentine

\begin{tabular}{|l|l|l|}
\hline PROPERTIES & BIO DENTIN & MTA \\
\hline Flexural strength & After 24 hours: $34 \mathrm{Mpa}$ & After 24 hours: 14.27 Mpa \\
\hline Radio opacity & $\begin{array}{l}3.5 \mathrm{~mm} \text { of equivalent } \\
\text { thickness of aluminium }\end{array}$ & $7.17 \mathrm{~mm}$ of equivalent thickness of aluminium \\
\hline pH & 12 & 9.5 to 11 \\
\hline Discoloration & It exhibits colour stability & $\begin{array}{l}\text { It causes discoloration of tooth due to the } \\
\text { presence of bismuth oxide and other heavy } \\
\text { elements }\end{array}$ \\
\hline Cost & $\begin{array}{l}\text { Single capsule costs around } \\
1000 \mathrm{NR}\end{array}$ & $\begin{array}{l}\text { Per gram costs around 3000-4000INR. Single } \\
\text { application costs around 300-400INR. }\end{array}$ \\
\hline Adhesion & $\begin{array}{l}\text { In addition to the micro } \\
\text { mechanical adhesion, there is } \\
\text { the formation of "mineral } \\
\text { infiltration zone" due to its } \\
\text { formation of cementum like }\end{array}$ & $\begin{array}{l}\text { Initially micromechanical adhesion followed } \\
\text { by cemtum like tissue formation later. }\end{array}$ \\
\hline
\end{tabular}

\section{SUMMARY:}

Biodentine can be used as permanent dentin replacement and temporary enamel whereas MTA can only be used as sub base ${ }^{5}$. However, there are certain limitation/drawbacks with both MTA and biodentine. The biodentine exhibits poor radioopacity and lower washout resistance whereas MTA shows discoloration, longer setting time, toxic elements in its composition 7 . Quest for newer materials are never ending especially in the field of dental science. Number of new materials are being formulated and tested every day to deliver a good clinical performance. One such is biodentine which has an increased potential to revolutionize the management of affected tooth in the field of operative dentistry and Endodontics. Although there has been increasing use of bioceramics and evident proof of its clinical outcomes, further studies are still required in this area.

\section{CONCLUSION:}

In a world full of continuous innovation, successful treatment outcomes can be achieved not just by different materials, but primarily by clinician's knowledge on these materials and skill to perform procedures precisely to achieve healing, restore function for the patient.

FINANCIAL SUPPORT AND

SPONSERSHIP:

$\mathrm{Nil}$

\section{CONFLICTS OF INTEREST:}

There are no conflicts of interest 


\section{REFERENCES:}

1. Torabinejad M, Watson TF, Pitt Ford TR. Sealing ability of a mineral trioxide aggregate when used as a root end filling material. J Endod 1993;19(12):591-95.

2. Torabinajad M, Chivian N. Clinical applications of mineral trioxide aggregate. J Endod 1999; 25(3):197-205.

3. Parirokh M, Torabinejad M. Mineral trioxide aggregate: A comprehensive literature review-Part III: Clinical applications, drawbacks, and mechanism of action. J Endod. 2010; 36(3):400-13.

4. Kaubi G, Colon P, Franquin JC. Clinical evaluation of the performance and safety of a new dentine substitute, biodentine, in the restoration of posterior teeth-a prospective study. Clin Oral Investig 2013;17(1):243- 49.

5. Sealing ability of a mineral trioxide aggregate when used as a root end filling material. J Endod 1993;19(12):591-95.

6. Torabinajad M, Chivian N. Clinical applications of mineral trioxide aggregate. J Endod 1999; 25(3):197-205.

7. Parirokh M, Torabinejad M. Mineral trioxide aggregate: A comprehensive literature review-Part III: Clinical applications, drawbacks, and mechanism of action. J Endod. 2010; 36(3):400-13.

8. Kaubi G, Colon P, Franquin JC. Clinical evaluation of the performance and safety of a new dentine substitute, biodentine, in the restoration of posterior teeth-a prospective study. Clin Oral Investig 2013;17(1):243- 49.

9. Elumalai D, Kapoor B, Tewrai RK, Mishra SK. Comparison of mineral trioxide aggregate and biodentine for management of open apices. J Interdiscip Dent 2015;5(3):131-35

10. Han L, Okiji T. Bioactivity evaluation of three calcium silicate based endodontic materials. Int Endod J 2013;46(9):80414

11. Mandeep Kaur, Harpreet Singh, Jaidev Singh Dhillon, Munish Batra, Meenu Saini. MTA versus Biodentine: Review of literature with a comparative analysis. J Clin Diag Res. 2017 Aug, Vol-11(8): ZG01- ZG05

12. Luo Z, Li D, Kohli MR, Yu Q, Kim S, He WX. Effect of Biodentine on the proliferation, migration and adhesion of human dental pulp stem cells. J Dent 2014;42(4):490 